DOI 10.31558/2519-2949.2021.4.4

УДК: $14[304+32.019 .5]: 316.77$

ORCID ID: https://orcid.org/0000-0002-8256-7267

Гайдаєнко П. Л., Південноукраӥнський національний педагогічний

університет ім. К. Д. Уиинського

\title{
РОЛЬ ОСОБИСТОСТІ ЛІДЕРА У ВИРІШЕННІ КРИЗОВИХ СИТУАЦІЙ В КРАЇНІ
}

У статті проаналізовано специфіку та проблемні аспекти формування та перебігу різних кризових ситуаиій та ролі особистісних якостей політичних лідерів на стратегії їх вирішення, щуо $\epsilon$ досить актуальною темою досліджень у сучасній політичній научі і політичній практиці. Саме в аналізі впливу особистісних якостей політичного лідера на вирішення кризових ситуацій в крайні полягають мета і відповідні завдання статті.

Було застосовано такі методи дослідження, як метод аналізу особистості політика, статистичний метод, метод функиіонального порівняння, метод прийняття рішень та контент-аналізу.

З'ясовано ключові особливості кризових ситуацій, їхні види та вплив на сферу політики. Визначено основні засади політичного лідерства, якості лідера та значення рішень, що ним приймаються. На прикладі аналізу діяльності політичних лідерів двох краӥн у період однісї кризи, з'ясовано основні стратегії взаємодії політичних лідерів з електоратом та чинними політичними елітами та їх вплив на вихід з кризової ситуащії. Обгрунтовано, щяо образ та особистість політичного лідера впливає не лише на сприйняття та підтримку електорату та апарату влади, а й на довготривалість иієї підтримки під впливом кризової ситуації.

Показано, що у результаті иььго політичний лідер або надалі дотримується обраної стратегіï, або поступається своєю стратегією і в пошуках підтримки “метушиться" та приймає низку необгрунтованих рішень, звісно і результати такої діяльності разюче відрізняються. Це підтверджено політичними подіями в Німеччині та Греції, де дві зовсім різні особистості політичних лідерів ініціювали низку важливих політичних змін та процесів глобального значення в період кризи євро.

Підсумовано, що особистість політичного лідера є ключовим джерелом змін у країні під час кризової ситуаиії. Саме діяльність та рімення політичного лідера визначають стратегію виходу з кризової ситуації та подальші трансформації в краӥні.

Ключові слова: політична комунікачія, політичне лідерство, влада, кризова ситуація, особистість лідера.

Вступ. У політичному становищі тієї чи іншої країни настає етап, що характеризується різким загостренням протиріч, збільшенням невдоволення еліт або населення політикою влади, нездатністю держави у повній мірі виконувати свої управлінські функції, виникненням гострих соціальних та політичних конфліктів. Порушення звичного ходу подій, поява нетипових для політичного порядку форм активності, як усередині політичної еліти, так і серед широких верств населення, зазвичай позначається поняттям «криза».

Серед причин кризових станів можна знайти не тільки об'єктивні економічні детермінанти або особливості впровадження державної політики, які призвели до конфлікту. Уся історія людство продемонструвала колосальний вплив лідерської особистості не тільки на виникнення криз, але і на їх подолання. Саме аспект лідерства може стати вирішальним у ситуації соціально-політичного конфлікту. Комунікація з суспільством, вплив на суб'єктів політичних відносин у часи кризи безперечно $є$ актуальною проблемою не тільки в науковій літературі алн і в політичній практиці.

Мета та завдання. Метою статті $є$ виявленя впливу особистісних якостей політичного лідера на вирішення кризових ситуацій в країні і визначення важливості цього впливу.

Методи дослідження. У статті було застосовано такі методи дослідження, як метод аналізу особистості політика, статистичний метод, метод функціонального порівняння, метод прийняття рішень та контент-аналізу. 
Результати. Перманентне виникнення соціально-політичних криз у сучасному світі та їх помітний вплив на всі сфери життя суспільства визначають нагальну потребу осмислення їх причин, динаміки, технологій та способів врегулювання. Безумовно, соціально-політична криза має свою специфіку, що обумовлено не лише сферою його виникнення, а й вкрай мінливим характером перебігу під впливом безлічі факторів.

Систематизуючи визначення політичної кризи як явища, можна стверджувати, що це соціальний та політичний стан суспільства, при якому на основі різкого загострення соціально-політичних протиріч порушується їх стабільність, нормальне функціонування та розвиток [20]. Під поняттям «політична криза» розуміється етап у розвитку політичного об'єкта (держави, влади, конкретної політики, парламенту, режиму, політичної системи, уряду тощо), який характеризується порушенням рівноваги однієї чи кількох базових підсистем у процесі їхнього функціонування, внаслідок чого змінюється сутність об’єкта, порушується регулярність політичної взаємодії [5, с. 374].

Доцільно виділити два параметри, що відображають багатоплановість кризових процесів у політиці. По-перше, масштаб кризи: криза може охопити всю політичну інституційну систему, набути загальнонаціонального розмаху, але може обмежитися рамками окремого інституту, політичної організації, системи регіонального управління. Спрощено уявімо це у вигляді дихотомії «національне - локальне».

По-друге, кризи необхідно розрізняти з їхньої глибині, тобто, за ступенем руйнівного впливу на політичний порядок. Одні кризи можуть супроводжуватися повним руйнуванням нормативного простору політичних відносин (аномія), інші призводять до часткового розмивання політичного порядку, у якому порушення одних, найбільш одіозних нормативних обмежень, не призводить до відторгнення інших правил інституційних взаємодій (дихотомія «аномія частковий безлад»). З’єднання цих двох дихотомій дозволяє сформулювати чотири види політичних криз [Див. детал.: 6].

Кризи-революції відрізняються розпадом всіх основних інституційних структур, що забезпечують відтворення системи політичних владних відносин та державного управління. 3 поглибленням кризи відбувається руйнування політичного нормативного порядку, політичні взаємодії стають хаотичними, що веде до розвалу політичної системи. Процеси, що протікають в умовах політичної аномії, відрізняються непередбачуваністю і заслуговують на спеціальний розгляд, що буде зроблено нижче.

Кризи-потрясіння $€$ частковою тимчасовою дестабілізацією політичного інституційного порядку. Як правило, такі кризи виявляються в зростанні невдоволення політикою правлячого класу, в активізації протестних рухів всій країні, у готовності широких верств населення підтримувати вимоги опозиційних сил. Владні еліти знаходяться у невизначеному положенні, вони відчувають труднощі у виборі способів регулюючого на маси. Політична система відчуває сильну внутрішню напругу, але механізми відтворення інституційних відносин ще не зруйновані, оскільки люди у своїй масі ще втратили «почуття порядку». Вони чи не готові йти напролом і будь-якою ціною добиватися задоволення своїх вимог, або усвідомлюють наслідки можливого політичного хаосу, або сподіваються на можливість вирішення виниклих проблем з допомогою законних способів на уряд. У свою чергу правляча еліта може запропонувати рішення, що стримують зростання масового невдоволення, і одночасно блокувати дії тих, хто здатний своїми діями підняти градус масових настроїв до критичного рівня.

Кризи-потрясіння відкривають можливості для оновлення системи політичної влади, але при цьому зберігають загальні принципи конституювання. Зміни носять еволюційний характер, вони дозволяють інституціоналізувати і включити в нормативний, що склався раніше, порядок нових моделей політичних взаємодій, не порушуючи саму систему, не вкладаючи їх у глибокий політичний хаос.

Кризи-руйнування відрізняються локальним характером аномічних процесів, що зачіпають окрему політичну організацію чи інституційну освіту. Знецінюються та втрачають свою регулюючу функцію норми, що визначають порядок політичних взаємодій в окремому сегменті політичної системи. Глибокі локальні кризи або завершуються руйнуванням відповідної політичної структури, або перетворюються на вогнище безнормності, аномії, що поступово розповсюджується на інші сегменти політичної системи. Перший варіант розвитку кризи вражає структур, які займають периферійне місце в політичній системі, наприклад, для низки політичних партій, громадських організацій, зникнення яких загалом для політичної системи проходить без будь-яких наслідків [12]. 
Якщо ж глибока криза вражає системоутворюючу політичну структуру, то в цьому випадку вона стає осередком поширення девіантної поведінки на всю політичну систему. Прикладом може бути глибока урядова криза, викликана гострими протиріччями всередині правлячого класу i вилився в нездатність кабінету міністрів виконувати свої основні функції. Оскільки уряд займає особливе місце у системі державної влади та державного управління, дезорганізація даного інституційного освіти неминуче призведе до поширення аномічних процесів протягом усього політичну систему [5, с. 374].

Кризи-обурення - це неглибокі локальні потрясіння політичної системи. Люди, котрі вступають у взаємодії з конкретного приводу, починають демонструвати моделі поведінки, які не укладаються в прийняті рамки, порушуючи правила, що склалися, й підсилюючи невизначеність, що є важливою ознакою кризового процесу. Однак напруга в функціонуванні окремих інститутів і організацій, яка виникає внаслідок цього, носить порівняно нетривалий характер і не підриває основні норми, що регулюють відповідні сегменти політичних взаємодій. Виникає урядова криза, але на відміну від аналогічної кризи-руйнування для неї характерно прагнення сторін, незважаючи на розбіжності, діяти в рамках правового поля, шукати компроміси, домовлятися про нові правила взаємодій.

Кризи-обурення - найбільш поширений вид криз, вони протікають постійно в різних сегментах політичної системи. Більше того, саме ці кризи відображають природний хід функціонування будьякої інституції або політичної організації [12].

Зростання кризових процесів в економіці, ускладнення механізмів їі функціонування, динамічні зміни виробничих технологій, загострення конкуренції, глобалізаційні та ряд інших процесів останніх десятиліть минулого століття зумовили інтерес до діяльності харизматичних лідерів і в організаційній сфері. У період політичних криз значно посилюється роль впливів лідерів громадських думок [Див., напр.: 7; 9].

Необхідність у лідерстві виникає тоді, коли ситуація, в яку через обставини, що склалися, втягнуто великі групи людей, вимагає оцінки та розгортання необхідних дій. У невеликих групах лідерство може бути неформальним та переходити від однієї особи до іншої тощо. У великих організованих групах виникає потреба в офіційному лідерстві. Для політичного лідера, який обіймає урядову посаду, займатися політикою - це не тільки професія. Відомий Макс Вебер відзначає, що кар'єра політика передбачає такі внутрішні втіхи, як відчуття влади, відчуття того, що тримаєш у руках пульс історично важливого політичного процесу. Макс Вебер виділяє три якості, вирішальні для політика: пристрасть, почуття відповідальності, спроможність внутрішньо зібрано і спокійно піддатися впливу реальностей. При цьому дослідник підкреслював, що політика - це повільне буріння твердих пластів суспільства [2, с. 142].

Суб'єктивна сторона лідерства виявляється через особистісні прояви лідера. Лідерство як різновид влади, виявляє специфіку через їі спрямованість з верху до низу, а також через те, що іiі носієм виступає не більшість, а одна людина або група осіб [12]. Жан Блондель зазначає, що політичне лідерство - це «влада, здійснювана одним або декількома індивідами для того, щоб спонукати членів націй до дій» [14]. Лідерство як управлінський статус, соціальна позиція пов’язане iз прийняттям рішень та керівною посадою. Така інтерпретація лідерства випливає зі структурнофункціонального підходу, що припускає розгляд суспільства як складної, ієрархічної організованої системи соціальних позицій і ролей. Заняття в цій системі позицій, пов'язаних з виконанням управлінських функцій (ролей), і дає людині статус лідера [10, с. 132]. Іншими словами, як відзначає Л. Даунтон, лідерство - це «становище в суспільстві, що характеризується здатністю особи, яка це становище займає, скеровувати й організовувати колективну поведінку деяких або всіх його членів» [3, с. 71]. Феномен лідерства виникає і реалізується тільки в суспільному середовищі. Феномен лідера - це визнання, виявлення, застосування природних психофізичних, розсудливорозумових та розпорядчо-організаційних відмінностей людей. Саме ці відмінності, особливі властивості та їх застосування характеризують лідерство як вплив на інших людей [14].

Г. Атаманчук та А. Гірник серед найважливіших якостей політичного лідера визгвчають:

1. Природні якості: а) зовнішні дані; б) психологічний тип особистості; в) комунікативні здібності; г) рефлективність; д) емпатійність.

2. Набуті (в процесі виховання, навчання, професійної діяльності) якості: а) моральні цінності; б) фізичне та психічне здоров'я; в) володіння навичками міжособистісного спілкування; г) життєвий досвід; д) професійна компетентність; е) рівень загальної культури; є) захоплення.

3. Соціальні характеристики: а) офіційна посада; б) походження; в) зв'язок з різними соціальними группами; г) родинний стан; д) суспільна діяльність. 
4. Політичні характеристики: а) політична платформа; б) партійна символіка; в) партійна діяльність [1, с. 105].

На думку Д. Ольшанського, найважливішими рисами, на вивчення та врахування сформованості яких має звертатися увага у визначенні психологічного портрета політичного лідера, $€$ :

1) індивідуально-особистісні риси: винятковість («ексклюзивність»), впевненість у собі та в своїй справі, сила;

2) соціальні риси: позиція «слуги суспільства», турбота про людей, добре знання їхніх проблем, прагнення поліпшити життя народу;

3) індивідуально-енергетичні риси: ентузіазм, бадьорість, оптимізм, провокування позитивних емоцій;

4) соціально-енергетичні риси: вміння впливати налюдей, рішучість, енергія, воля, наполегливість;

5) соціально-моральні риси: високі моральні якості, відповідність «суспільному ідеалу».

Останнє має велике значення: адже такі набори (патерни) рис варіюються в різних країнах і на різних етапах історії. Щоправда, як стверджує Д. Ольшанський, жодного «стійкого» набору рис політичного лідера немає і не може бути в принципі [8, с. 123].

Цікавим для вивчення є досвід політичного лідерства в країнах Центральної та Східної Європи (ЦСЄ), зокрема: Польщі, Угорщині, Словаччині, Румунії і Чехії, для яких останнє десятиліття характеризується суттєвим економічним зростанням та значним підвищенням рівня життя населення [4, с. 154]. Разом з тим притаманною рисою політичного життя, усіляких політичних кампаній, парламентських і президентських виборів у цих країнах даного періоду можна назвати суттєву радикалізацію політичної діяльності. Ї̈ї наслідком стало послаблення політичної ролі проєвропейських і проринкових партій, втрата ними місця у владі на користь популістських, націоналістичних чи й відверто праворадикальних партій [10, с.116]. Так, у Польщі, Угорщині, Чехії до влади прийшли політичні сили, для яких характерним є чітке прагматичне ставлення до зовнішньополітичної проблематики перш за все крізь призму національних інтересів. Як новоприйняті члени $\mathrm{CC}$, вони наполегливо пропонують переглянути умови членства у цій спільноті держав, невтомно і сміливо ратують за посилення національної ролі кожної державичлена ЄС в економічній, освітній, медійній сферах наддержавного європейського буття [4, с.111]. Одночасно з цим, причому незалежно від суб'єктів політичного олімпу: націонал-лібералів, ультраправих радикалів, соціалістів, в усіх країнах ЦСЄ спостерігається ще одна знакова для новітнього періоду функціонування будь-якої держави тенденція, сутністю якої стало згортання соціальних програм та скорочення витрат на соціальну сферу [11, с.221]. Необхідно зазначити, що соціально небезпечні наслідки вищезазначених тенденцій, такі як, наприклад, радикалізація політичної діяльності, спалахи ксенофобії, екстремізму тощо, по-різному обгрунтовуються науковцями та практиками. Так, одні з них переконані, що проблема полягає, з одного боку, у незрілості суспільства, з іншого - у надмірній консервативності та нездатності сформованих у результаті реалізації євроінтеграційної стратегії політичних інститутів враховувати різноманітність центрально-східноєвропейських суспільств [10]. Інші вчені пояснюють такий стан речей у країнах ЦСС їх елементарною втомою від безкінечності реформ [4]. Радикалізація центрально-східноєвропейської політики є наслідком та результатом невдалої спроби надмірної поспішності переходу від капіталізму до соціалізму без урахування розмаїтості та полівалентності як об'єктивних, так і суб'єктивних політичних та державно-адміністративних процесів у цих країнах [10, с.115]. За таких обставин саме на лідерів держав покладається особлива роль з врегулювання ситуації, підтримання політичної та економічної стабільності на кожному етапі проведення демократичних державних та суспільних перетворень.

У часи кризи політичні лідери розриваються між закликами до сильного керівництва та необхідністю зберігати дозвіл на діяльність серед своїх виборців. Особливо яскравим прикладом цього є скрутне становище голов європейських держав і урядів під час криз. Оскільки, крім внутрішньої напруженості між політичним лідерством і демократією, у європейській багаторівневій системі мають балансувати вимоги багатьох груп потенційних послідовників, стикаючись зі слабкими та суперечливими векторами законного лідерства. Цей внесок представляє основу, за допомогою якої можна систематично оцінювати напруженість законного європейського лідерства. Він застосовує цю структуру до двох різних політичних лідерів, які були ключовими для врегулювання кризи євро, канцлера Німеччини Ангели Меркель і прем'єр-міністра Греції Алексіса Ципраса в їхніх спробах пройти канатом між законним і рішучим керівництвом ЄС. 
Ангела Меркель була канцлером Германії з 2005 року і лідером німецької християнськодемократичної партії, ХДС, з 2000 року. Вона одна 3 двох Європейських лідерів, які пережили кризу євро. 3 моменту початку кризи Меркель очолювала два коаліційних уряди. Не дивлячись на кризу євро, до початку міграційної кризи осені 2015 року, позиція Меркель ніколи серйозно не піддавалася сумніву [20].

3 міжнародної точки зору, це може здатися цікавим, оскільки канцлер Німеччини піддавалася різкій критиці за неспроможність забезпечити керівництво, необхідне для виведення Свропи з кризи євро [16]. В якості обраного лідера економічного центру Європи, серед потенційних дослідників Меркель є німецький народ, iï партія та інші члени уряду Германії, а також іiі колегія HSG в Свропейській раді.

Меркель можна розглядати як законного політичного лідера німецького народу за виборчим вектором. Однак зв'язок Меркель з німецьким народом також частково корениться у векторі соціальної ідентифікації. На перший погляд, як східногерманська жінка-лідер з академічним вихованням, Меркель здається маловірогідним кандидатом на роль прототипового німця. Однак, канцлер завжди уникала змішування своєї публічної особистості з елементами особистого життя, через що середньостатистичному німцю було важко встановити з нею відносини. В той самий час вона створила навколо себе ауру нормальності. Це дає людям почуття знайомості, яке добре працює в еголітарній державі, такій як Німеччина [Див.: 14; 20]. Так, як відомо, ще в 2008 році Меркель використовувала образ скромної швабської домохазяйки, який так добре знайшов відгук у людей, що Меркель, яка не $\epsilon$ ні швабкою, ні домохазяйкою, стала швидко асоціюватися $з$ цим жіночим німецьким стереотипом[20].

Більше того, незважаючи на те, що вона не є провидцем-лідером, ця асоціація з бережливістю прив'язувала iï до їі виборців в ідеологічному значенні. Як і більшість німців, Меркель підтримує ордоліберальну економічну школу думки. Однак вона більше ідейний дослідник і тому, мабуть, не втикликала такі ж агресивнві емоції, як інші представники в німецькому фінансовому істеблішменті. Та незважаючи на те, що Меркель стала міжнародним пропагандистом ордолібералізму, вона, не будучи експертом в економічних і монетарних питаннях, в цілому керувала міністром фінансів Німеччини Вольфгангом Шойбле, очоливши переговори шодо кризи євро. Вона неохоче втручалася в прийняття життєво важливих політичних рішень, а потім часто використовувала більш примирений і компромісний тон [Див.: 19, с. 25-41]. Що стосується німецького народу, то ії лідерство, таким чином, грунтується переважно на виборчому векторі та соціальній ідентифікації, а не на векторах досвіду чи ідеології.

У той час як економічний спад і політична нестабільність, викликані кризою євро, нанесли серйозний удар по легітимності виробництва всіх європейських обраних і технократичних лідерів, всередині країни керівництво Меркель, несомненно, було ефективним. Німеччина постраждала від кризи, i іноді в ії громадян виникали серйозні сумніви щодо курсу, який вона визначила, і компромісу, на який вона пішла. Однак у той же час Німеччина - одна з європейських держав, які зберегли свій статус Triple А та економічну силу [18].

Хоча Меркель є протилежністю ідеологічного лідера і піддавалася різкій критиці за ії ідеологічні пошуки жорсткої економії в англосаксонській пресі та наукових колах [20], ії підхід дійсно отримав сильну ідеологічну підтримку серед лідерів таких країн як Австрія, Фінляндія, Словенія та Нідерланди. Для них Меркель була високо оціненим ордоліберальним представником під час розтину другої та третьої допомоги Греції, коли вони фактично змусили ії зайняти ще більш агресивну позицію [18]. Замість того, щоб вказувати на відсутність лідерства, варто зазначити результат цієї битви, якийможна розглядати як ілюстрацію ідеологічної гегемонії Німеччини [17].

Парадокси легітимності не давали спокою Алексису Ципрасу. Ципрас був прем'єр-міністром Греції 325 січня 2015 року і лідером малоймовірної коаліції його лівої партії Syriza і правих незалежних греків. Хоча ця коаліція була заснована на загальних принципах протидії умов перших двох європейських заяв про фінансову допомогу, у липні 2015 року Ципрас погодився на третій пакет допомоги при ще більш жорстких умовах. Це призвело до розколу всередині «» і новими виборами 20 вересня 2015 року. Ципрас був переобраний прем'єр-міністром і продовжував редагувати в коаліції з незалежими греками. Як прем’єр-міністр, він $є$ лідером грецького народу, коаліційного уряду та своєї партії.

Після перемоги на двох загальних виборах за один рік і в якості обраного лідера партії «Сириза» внутрішне керівництво Ципраса легітимно в виборному сенсі. Крім того, його популярність часто пояснюється його ліворадикальними ідеологічними переконаннями. Однак поворот подій впродовж першого року його перебування при владі демонструє, що Ципрас був у значній мірі неспроможний 
забезпечити своєму електорату або партіям бажаний результат або ліву утопію соціального забезпечення, боротьбу з капіталізмом, корупцією, ухиленням від сплати податків та зменшенням дій податків. Це говорить про те, що в основі постійного успіху Ципраса на виборах лежить цей вектор легітимного лідерства, сильного та шкідливого у сфері ідентичності.

Аналізуючи його політичне минуле та публічні заяви, можна побачити явні ідеологічні аспекти лідерства Ципраса. Syriza - це коаліція кількох радикальних лівих фракцій, а Ципрас почав як лідер молодіжного руху радикальних лівих, антиглобалістської партії Synaspismos. Після виборів Ципрас виявив наміри заморозити приватизацію, відновити мінімальну плату за роботу, найняти тисячі державних службовців, звільнених у рамках раніше заключного оголошення про фінансову допомогу, і боротися з ухиленням від сплати податків і корупцією з боку багатих. Більше того, у березні 2015 року уряд прийняв закон, що дозволяє надавати екстрену допомогу, безкоштовну електроенергію та талони на харчування бідним громадянам [13]. Ципрас також пішов віч на віч зі своїми Свропейськими партнерами, щоб узгодити умови, пов'язані з обов'язковою виплатою наступного транша позик, запланованого на лютий 2015 року. Після шести років рецесії та пагубної реформи жорсткої економіки обіцяний U-поворот в економічній політиці, безсумнівно, був важливим фактором для багатьох греків, що підтримали керівництво Ципраса.

Однак угода, заключена Ципрасом у лютому 2015 року з партнерами в єврозоні про отримання позик протягом чотирьох місяців, породила попереднє існування сумнівів в силу його ідеологічних переконань [20]: ліва платформа антикапіталистів, що складала близько третини Syriza, звинувативши Ципраса в тому, що він скритий соціал-демократ, поставила під сумнів його лідерство і закликала його домагатися Грекситу [15]. Однак, оскільки Греція все ще була під загрозою дефолту, розпочались нові переговори з СС. Після кількох місяців безладних переговорів про умови наступної операції та серйозного порушення відносин з кредиторами, Ципрас відмовився від переговорів, оголосивши остаточну пропозицію «принизливою» [13]. Коли наступні дебати в грецькому парламенті не привели до угоди з цього питання, Ципрас скликав референдум i виступив за відклонення угод. 5 липня 61 \% греків проголосували проти референдуму [16].

Тим часом важка фінансова ситуація змусила грецький уряд запровадити контроль за рухом капіталу та оголосити дефолт із платежів МВФ. Це фактично поклало край другому пакету допомоги. Коли уряд мав виплатити ще 6,6 млрд євро Свропейському центральному банку, а в грецьких банків закінчилися гроші, Ципрас раптово здійснив повний розворот [20]. Замість того, щоб віддати належне референдуму і наслідувати перевагу радикальних лівих фракцій у його партії Грексит, Ципрас уклав угоду з трьома проєвропейськими партіями в грецькому парламенті і повернувся до Брюсселя, щоб почати переговори щодо третього пакету допомоги [18]. Більше того, незважаючи на те, що умови для цього пакету були навіть жорсткішими, ніж умови раніше відхиленого другого пакета фінансової допомоги, Ципрас продовжив домагатися згоди грецького парламенту на угоду з 229 голосами проти 64. Проте через розкол всередині партії «Сириза» уряд втратив парламентську більшість, і Ципрас закликав до нових виборів. Незважаючи на те, що він повернувся до своїх передвиборчих обіцянок і скасував результати референдуму, 20 вересня 2015 року Ципрас був переобраний прем'єр-міністром, втративши лише чотири місця, i продовжив правити разом із незалежними греками.

Ципрас явно не виправдав переваг і ідеологічних надій народу та його партії. Більше того, спостерігачі сходяться на думці, що груба переговорна тактика Ципраса та його команди завадила досягненню кращого результату для Греції [14]. Тим не менш, грецький народ і більшість членів партії Сириза продовжували підтримувати Ципраса як свого лідера. Така лояльність перед тим, що, безсумнівно, було «болісними втратами для команди господарів» [20], вказує напрямок вектора соціальної ідентифікації.

Дії Ципраса підтверджують це. Задовго до виборів 2015 року Ципрас почав вибудовувати інклюзивну грецьку ідентичність, яка поєднує, здавалося б, різні демографічні групи під спільним знаменником «простих людей», які стали жертвами грецького та європейського істеблішменту. У своїх виступах Ципрас пообіцяв «відновити їхню гідність та представляти їхні інтереси проти грецького та європейського істеблішменту, тим самим порушивши омерту, що оточувала «історію успіху» єврозони» [14]. Виявлення чіткої чужої групи допомогло об'єднати широку внутрішню групу, яку Ціпрас прагнув мобілізувати. У своїй популістський риториці він провів чіткий поділ між ворогуючими таборами «вони» проти «нас»: могутня, багата еліта проти непривілейованих, які страждають від багаторічної безгосподарності та жорсткої економії, накладених попередніми урядами та європейськими партнерами. Зокрема, Німеччина [20]. Відповідно до цього лідера ідентичності Ципрас сформував уряд з іншими, які виступають проти істеблішменту та проти жорсткої економії, 
але ідеологічно далекими незалежними греками. Більш того, його першою дією після вступу на посаду було покласти квіти до меморіалу грецьким бійцям опору, убитим німецькими військами у Другій світовій війні, та заснувати комітет для вивчення вимог Греції щодо відшкодування збитків Німеччині за війну [13]. Ця комбінація ідеологічного та особливо особистісного лідерства забезпечила Ципрасу стійку підтримку його внутрішніх послідовників, оскільки, незважаючи на поразку у всіх битвах, «Ціпрас протистояв Німеччині так, як жоден інший грецький лідер».

Ципрас керував ідентичністю, яка так добре служила йому всередині країни. Парадоксально, але особистісне лідерство, яке зрештою допомогло Ципрасу продати угоди з іншими лідерами єврозони всередині країни, здебільшого на їх умовах, дуже підірвало його легітимність у Європейській раді. Це, у свою чергу, завадило йому укласти вигіднішу угоду для свого народу [14].

Нарешті, коли ні переговори, ні ідеологічна пристрасть, ні лідерство у питаннях ідентичності не привели його до своїх європейських партнерів, Ципрас спробував задіяти електоральний вектор легітимності, скликаючи референдум у липні 2015 року. Однак на європейському рівні це зіставило негативне голосування грецького народу проти законного права (мешканців) інших держав єврозони накладати умови на позики, які їм запропонували надати. У світлі народної волі іï партнерів у взаємозалежному багаторівневому Європейському союзі бажання Греції залишитись у єврозоні було просто несумісне з відмовою від пакету фінансової допомоги [20].

Висновки. Випадки канцлера Німеччини Ангели Меркель та прем'єр-міністра Греції Ципраса показують, що, незалежно від свого становища у владі, вони стикалися з аналогічними парадоксами у своїх спробах упоратися з кризою, а рішення та вихід 3 цих ситуацій були зовсім різними та залежали від особистісних якостей політичних лідерів.

Оскільки все лідерство $є$ політичним і жодна політика чи регулювання не приносить користі всім, федеральне та централізоване керівництво страждатиме від парадоксів власної легітимності.

\section{Бібліографічний список:}

1. Атаманчук Г., Гірник А. Політичний менеджмент. Теорія і практика політтехнологій. Рівне: Перспективи, 2005. 222 с.

2. Вебер М. Харизматическое господство. Социологические исследования. 2009. № 3. С. 139-147

3. Гринстайн Ф. Личность и политика. Социально-политические науки. 2011. № 10. С. 67-74

4. Демократическое правовое государство и гражданское общество в странах Центральной и Восточной Европы. Москва, 2005. 184 с.

5. Кармазіна М. С. Криза політична. Політична енциклопедія. Київ. Парламентське видавництво. 2011. C. $373-374$

6. Ковалевський В. Політична комунікація як інструмент подолання кризових явищ. 2015.

URL: http://periodicals.karazin.ua/politology/article/view/3218

7. Лозинський О. М. Політична психологія. Львів. 2021. 228 с.

8. Ольшанский Д. В., Пеньков В. Ф. Политический консалтинг. Санкт-Петербург. 2015. С. 122-124.

9. Онуфрик Я. Б. Психологічні технології виборчої кампанії: настрої суспільства, політичний імідж, чорний піар, маніпуляція свідомістю. Чернівці. 2013. 87 с.

10. Рудич Ф. М. Порівняльна політологія: Навч. посіб. Київ. 2006. 321 с.

11. Хрестоматия по политической психологии / сост. и науч. ред. Шестопал Е. Б. Москва. 2012. 344 с.

12. Чекменёва Т. Г. Политические кризисы: понятие и типология, 2016. URL: http://vadim-

galkin.ru/politics/policy/politicheskie-krizisy-ponyatie-i-tipologiy

13. Foy H., and K. Hope. Greeks Dance but Tsipras Faces Big Test. Financial Times, July 7. 2015.

URL: https://next.ft.com/.

14. Haslam S. A., Reicher S. D., Platow M. J. The New Psychology of Leadership: Identity, Influence and Power. London: Psychology Press, 2011

15. Hope K. Somersaulting Tsipras Prepares Next Trick. Financial Times, 2015. August 22.

16. Nardelli A. Angela Merkel: 10 Years in 10 Charts. The Guardian, 2015. September 18.

URL: http://www.theguardian.com/news/datablog/2015/sep/18/angela-merkel-10-years-germany-chancelloreconomy-cdu.

17. Schoeller M. G. Providing Political Leadership? Three Case Studies on Germany's Ambiguous Role in the Eurozone Crisis. Journal of European Public Policy, 2016. № 24 (1): P. 1-20.

18. The German Mentality: Hail, the Swabian Housewife, 2014. February.

URL: http://www.economist.com/news/europe/21595503-views-economics-euro-and-much-else-draw-culturalarchetype-hail-swabian.

19. Tsebelis G. Lessons from the Greek Crisis. Journal of European Public Policy, 2016. № 23 (1). C. 25-41.

20. Van Esch F. A. W. J. The paradoxes of legitimate EU leadership. An analysis of the multi-level leadership of Angela Merkel and Alexis Tsipras during the euro crisis.

URL: https://www.tandfonline.com/doi/full/10.1080/07036337.2016.1277716. 


\section{References:}

1. Atamanchuk G., Girnik A. Politichnii menedzhment. Teoriya i praktika polittekhnologii. Rivne: Perspektivi, 2005. 222 s. [in Ukrainian]

2. Veber M. Kharizmaticheskoe gospodstvo. Sotsiologicheskie issledovaniya. 2009. № 3. S. 139-147 [in Russian]

3. Grinstain F. Lichnost' i politika. Sotsial'no-politicheskie nauki. 2011. № 10. S. 67-74 [in Russian]

4. Demokraticheskoe pravovoe gosudarstvo i grazhdanskoe obshchestvo v stranakh Tsentral'noi i Vostochnoi Evropy. Moskva, 2005. 184 s. [in Russian]

5. Karmazina M. S. Kriza politichna. Politichna entsiklopediya. Kiïv. Parlaments'ke vidavnitstvo. 2011.

S. 373-74 [in Ukrainian]

6. Kovalevs'kii V. Politichna komunikatsiya yak instrument podolannya krizovikh yavishch. 2015.

URL: http://periodicals.karazin.ua/politology/article/view/3218 [in Ukrainian]

7. Lozins'kii O. M. Politichna psikhologiya. L'viv. 2021. 228 s. [in Ukrainian]

8. Ol'shanskii D. V., Pen'kov V. F. Politicheskii konsalting. Sankt-Peterburg. 2015. S. 122-124 [in Russian]

9. Onufrik Ya. B. Psikhologichni tekhnologiï viborchoï kampaniï: nastroï suspil'stva, politichnii imidzh, chornii piar, manipulyatsiya svidomistyu. Chernivtsi. 2013. $87 \mathrm{~s}$. [in Ukrainian]

10. Rudich F. M. Porivnyal'na politologiya: Navch. posib. Kiïv. 2006. 321 s. [in Ukrainian]

11. Khrestomatiya po politicheskoi psikhologii / sost. i nauch. red. Shestopal E. B. Moskva. 2012. 344 s. [in Russian]

12. Chekmeneva T. G. Politicheskie krizisy: ponyatie i tipologiya, 2016. URL: http://vadim-galkin.ru/politics/ policy/politicheskie-krizisy-ponyatie-i-tipologiy[in Russian]

13. Foy H., and K. Hope. Greeks Dance but Tsipras Faces Big Test. Financial Times, July 7. 2015.

URL: https://next.ft.com/.

14. Haslam S. A., Reicher S. D., Platow M. J. The New Psychology of Leadership: Identity, Influence and Power. London: Psychology Press, 2011.

15. Hope K. Somersaulting Tsipras Prepares Next Trick. Financial Times, 2015. August 22.

16. Nardelli A. Angela Merkel: 10 Years in 10 Charts. The Guardian, 2015. September 18.

URL: http://www.theguardian.com/news/datablog/2015/sep/18/angela-merkel-10-years-germany-chancellor-economy-cdu.

17. Schoeller M. G. Providing Political Leadership? Three Case Studies on Germany’s Ambiguous Role in the Eurozone Crisis. Journal of European Public Policy, 2016. № 24 (1). Pp.1-20.

18. The German Mentality: Hail, the Swabian Housewife, 2014. February. URL: http://www.economist.com/news/ europe/21595503-views-economics-euro-and-much-else-draw-cultural-archetype-hail-swabian.

19. Tsebelis G. Lessons from the Greek Crisis. Journal of European Public Policy, 2016. № 23 (1). S. 25-41.

20. Van Esch F. A. W. J. The paradoxes of legitimate EU leadership. An analysis of the multi-level leadership of Angela Merkel and Alexis Tsipras during the euro crisis.

URL: https://www.tandfonline.com/doi/full/10.1080/07036337.2016.1277716.

\section{Gaidaenko $P$. L. The role of the leader's personality in resolving crisis situations in the country}

The article analyzes the specifics and problematic aspects of the formation and course of various crisis situations and the role of personal qualities of political leaders in the strategy of their solution, which is a very relevant research topic in modern political science and political practice. It is in the analysis of the influence of personal qualities of a political leader on the resolution of crisis situations in the country are the purpose and relevant objectives of the article.

Research methods such as the policy analysis method, statistical method, functional comparison method, decision making method and content analysis were used.

The key features of crisis situations, their types and impact on the policy sphere are identified. The basic principles of political leadership, the qualities of a leader and the importance of decisions made by him are determined. On the example of the analysis of the activities of political leaders of the two countries during one crisis, the main strategies of interaction of political leaders with the electorate and current political elites and their impact on overcoming the crisis. It is substantiated that the image and personality of a political leader influences not only the perception and support of the electorate and the apparatus of power, but also the longevity of this support under the influence of the crisis situation.

As a result, it is shown that the political leader either continues to follow the chosen strategy, or gives up his strategy and in search of support "fusses» and makes a number of unreasonable decisions, of course, and the results of such activities are strikingly different.This is confirmed by the political events in Germany and Greece, where two completely different personalities of political leaders initiated a number of important political changes and processes of global importance during the euro crisis.

It is concluded that the personality of a political leader is a key source of change in the country during a crisis situation. It is the activities and decisions of the political leader that determine the strategy of overcoming the crisis and further transformations in the country.

Keywords: political communication, political leadership, power, crisis situation, leader 's personality. 